\title{
Incretin Mimetics and DPP-IV Inhibitors: New Paradigms for the Treatment of Type 2 Diabetes
}

\author{
Deborab Hinnen, ARNP, BC-ADM, CDE, FAAN, Loretta L. Nielsen, PhD, \\ Amy Waninger, BS, and Pamela Kushner, $M A, M D$
}

Incretin mimetics are a new class of pharmacological agents with multiple antihyperglycemic actions that mimic several of the actions of incretin hormones originating in the gut, such as glucagon-like peptide (GLP)-1. Dipeptidyl peptidase-IV (DPP-IV) inhibitors suppress the degradation of many peptides, including GLP-1, thereby extending their bioactivity. These agents seem to have multiple mechanisms of action for the treatment of type 2 diabetes mellitus (T2DM), including some or all the following: enhancement of glucose-dependent insulin secretion, suppression of inappropriately elevated glucagon secretion, slowing of gastric emptying, and decreased food intake. Exenatide (BYETTA ${ }^{\circledR}$ ) is the first incretin mimetic approved for clinical use by the US Food and Drug Administration. In phase 3 clinical trials, exenatide reduced $\mathrm{HbA}_{1 \mathrm{c}}$ by $\sim 1 \%$ and body weight by $\sim 2 \mathrm{~kg}$ in T2DM patients failing to achieve glycemic control with metformin and/or a sulfonylurea, with mild-to-moderate nausea the most common side effect. Several GLP-1 analogues and DPP-IV inhibitors are in late-stage clinical testing and may soon become available for treating T2DM patients. The use of these agents may provide an opportunity to bring about new improvements in diabetes care. (J Am Board Fam Med 2006;19:612-20.)

Type 2 diabetes mellitus (T2DM) is characterized by the emergence of postprandial (post-meal) and subsequently, fasting hyperglycemia (fasting plasma glucose concentrations $>125 \mathrm{mg} / \mathrm{dL}) .{ }^{1,2}$ Hyperglycemia results from a failure of pancreatic $\beta$-cells to secrete adequate insulin to compensate for insulin resistance in peripheral tissues. ${ }^{3,4}$ The increasing worldwide prevalence of T2DM (American Diabetes Association. 2006. [monograph on the Internet]. Total prevalence of diabetes and prediabetes. Available from: http://www.diabetes.org/ diabetes-statistics/prevalence.jsp) has major implications for both health care systems and affected individuals, particularly because of the vascular complications associated with this disease. The aim of pharmacological therapy for T2DM (Table 1) is to control hyperglycemia and, ultimately, to avert the serious complications associated with sustained

This article was externally peer reviewed.

Submitted 13 December 2005; revised 3 April 2006; accepted 6 April 2006.

From Mid America Diabetes Associates (DH), Wichita, KS; Amylin Pharmaceuticals Inc. (LLN), San Diego, CA; Eli Lilly and Company (AW), Indianapolis IN; and University of California, Irvine Medical Center (PK), Orange, CA.

BYETTA $^{\circledR}$ is a registered trademark of Amylin Pharmaceuticals, Inc.

Corresponding author: Debbie Hinnen, Mid America Diabetes Associates, 200 S. Hillside, Wichita, KS 67211 (Email: dhinnen@madiabetesa.com). tissue exposure to excessively high glucose concentrations. However, due to the complex nature of the disease and the progressive deterioration in pancreatic $\beta$-cell function, glycemic control remains difficult. Despite the use of intensive therapy, the United Kingdom Prospective Diabetes Study (UKPDS) found that glycemic control continued to deteriorate over time, ${ }^{5}$ and despite currently available therapies, the majority of T2DM patients in the United States continue to have poor diabetes control, as reflected by glycohemoglobin $\mathrm{A} 1 \mathrm{C}\left(\mathrm{HbA}_{1 \mathrm{c}}\right)$ concentrations greater than $7 \%$ in more than $60 \%$ of $\mathrm{T} 2 \mathrm{DM}$ patients. ${ }^{6-8}$

The most widely used combination of oral therapy for T2DM patients is metformin with a sulfonylurea. ${ }^{7,9-11}$ Both drugs can be safe and effective when used either as monotherapy or in combination, albeit with a risk of drug-associated side effects. ${ }^{7,9-11}$ The question of which therapies are best when this combination no longer produces acceptable glycemic control is a topic of significant debate. Addition of insulin or a thiazolidinedione are popular options, but each agent is associated with additional side effects, including weight gain, in a patient population that is generally overweight or obese. ${ }^{9,12-14}$ The reasons for weight gain in T2DM are many, and include compensatory eating to avoid hypoglycemia, decreased glucosuria, and de- 


\begin{tabular}{|c|c|c|c|}
\hline $\begin{array}{l}\text { Pharmacologic Treatment } \\
\text { Classes }\end{array}$ & Mechanism of Action & Effects/Characteristics & Adverse Events \\
\hline Biguanide (metformin) & $\begin{array}{l}\text { - Decrease hepatic glucose } \\
\text { production } \\
\text { - Decrease intestinal glucose } \\
\text { absorption } \\
\text { - Increase glucose uptake by } \\
\text { skeletal muscle and fat }\end{array}$ & $\begin{array}{l}\text { - Reduce blood glucose } \\
\text { concentration } \\
\text { - Increase sensitivity to insulin } \\
\text { - Reduce blood lipid levels } \\
\text { - Oral administration }\end{array}$ & $\begin{array}{l}\text { - Diarrhea } \\
\text { - Nausea } \\
\text { - Vomitting } \\
\text { - May cause lactic } \\
\text { acidosis }\end{array}$ \\
\hline Sulfonylureas & $\begin{array}{l}\text { - Stimulate pancreatic } \beta \text {-cell } \\
\text { insulin secretion }\end{array}$ & $\begin{array}{l}\text { - Reduce blood glucose } \\
\text { concentration } \\
\text { - Lower risk of hypoglycemia } \\
\text { than insulin } \\
\text { - Oral administration }\end{array}$ & $\begin{array}{l}\text { - Hypoglycemia } \\
\text { - Weight gain } \\
\text { - Nausea } \\
\text { - Vomiting }\end{array}$ \\
\hline Thiazolidinediones & $\begin{array}{l}\text { - Improve target cell response to } \\
\text { insulin } \\
\text { - Decrease hepatic glucose output } \\
\text { - Increase insulin-dependent } \\
\text { glucose uptake in skeletal } \\
\text { muscle and fat }\end{array}$ & $\begin{array}{l}\text { - Reduce blood glucose } \\
\text { concentration } \\
\text { - Beneficial alteration of blood } \\
\text { lipid levels } \\
\text { - Possible beneficial effects on } \\
\text { pancreas and cardiovascular } \\
\text { risk factors } \\
\text { - Oral administration }\end{array}$ & $\begin{array}{l}\text { - Alteration in liver } \\
\text { function indicators } \\
\text { - Anemia } \\
\text { - Detrimental cardiac } \\
\text { effects } \\
\text { - Edema } \\
\text { - Weight gain }\end{array}$ \\
\hline $\begin{array}{l}\text { Meglitinides and } \mathrm{d}- \\
\text { phenylalanine derivatives }\end{array}$ & $\begin{array}{l}\text { - Stimulate glucose-mediated } \\
\text { insulin secretion }\end{array}$ & $\begin{array}{l}\text { - Reduce blood glucose } \\
\text { concentration } \\
\text { - Reduce postprandial glucose } \\
\text { excursions } \\
\text { - Stimulates insulin secretion } \\
\text { - Oral administration }\end{array}$ & $\begin{array}{l}\text { - Hypoglycemia } \\
\text { - Diarrhea } \\
\text { - Weight gain }\end{array}$ \\
\hline$\alpha$-Glucosidase inhibitors & $\begin{array}{l}\text { - Inhibit pancreatic } \alpha \text {-amylase and } \\
\text { membrane-bound } \alpha \text {-glucosidase } \\
\text { enzymes } \\
\text { - Inhibit intestinal disaccharide } \\
\text { metabolism, delaying glucose } \\
\text { absorption }\end{array}$ & $\begin{array}{l}\text { - Reduce blood glucose } \\
\text { concentration } \\
\text { - Reduce postprandial glucose } \\
\text { excursions } \\
\text { - Level out daytime glucose } \\
\text { concentrations } \\
\text { - Disperse calories over time } \\
\text { - Weight neutral } \\
\text { - Oral administration }\end{array}$ & $\begin{array}{l}\text { - Abdominal pain } \\
\text { - Diarrhea } \\
\text { - Flatulence } \\
\text { - Possible elevated liver } \\
\text { enzymes }\end{array}$ \\
\hline Insulin and insulin analogues & $\begin{array}{l}\text { - Replace/supplement endogenous } \\
\text { insulin hormone to correct } \\
\text { deficiency }\end{array}$ & $\begin{array}{l}\text { - Reduce blood glucose } \\
\text { concentration } \\
\text { - Subcutaneous injection }\end{array}$ & $\begin{array}{l}\text { - Hypoglycemia } \\
\text { - Weight gain }\end{array}$ \\
\hline \multicolumn{4}{|c|}{ Potential therapeutics discussed in this article } \\
\hline $\begin{array}{l}\text { Incretin mimetics: Exenatide } \\
\text { (others in clinical testing) }\end{array}$ & $\begin{array}{l}\text { - Replace/supplement endogenous } \\
\text { incretin hormone(s) } \\
\text { glucoregulatory activity } \\
\text { - Adjunctive therapy with } \\
\text { metformin and/or sulfonylureas }\end{array}$ & $\begin{array}{l}\text { - Reduce blood glucose } \\
\text { concentration } \\
\text { - Reduce postprandial glucose } \\
\text { excursions } \\
\text { - Enhance glucose-dependent } \\
\text { insulin secretion } \\
\text { - Suppress inappropriately } \\
\text { elevated glucagon secretion } \\
\text { - Reduce food intake } \\
\text { - Slow gastric emptying } \\
\text { - Weight reduction or weight } \\
\text { neutral } \\
\text { - Possible beneficial effects on } \\
\text { pancreas (preclinical diabetes } \\
\text { models) } \\
\text { - Subcutaneous injection }\end{array}$ & $\begin{array}{l}\text { - Nausea } \\
\text { - Increased hypoglycemia } \\
\text { when administered } \\
\text { with sulfonylureas } \\
\text { - Awaiting clinical data } \\
\text { for combination with } \\
\text { other antidiabetic } \\
\text { treatments }\end{array}$ \\
\hline $\begin{array}{l}\text { DPP-IV inhibitors (clinical } \\
\text { testing) }\end{array}$ & $\begin{array}{l}\text { - Inhibit peptide hormone } \\
\text { metabolism by DPP-IV } \\
\text { enzyme, thus increasing blood } \\
\text { concentations of endogenous, } \\
\text { bioactive forms of GLP-1 and } \\
\text { other peptides }\end{array}$ & $\begin{array}{l}\text { - Reduce blood glucose } \\
\text { concentration } \\
\text { - Reduce postprandial glucose } \\
\text { excursions } \\
\text { - Weight neutral } \\
\text { - Possible beneficial effects on } \\
\text { pancreas and insulin sensitivity } \\
\text { (preclinical diabetes models) } \\
\text { - Oral administration } \\
\text { - Status of disease progression } \\
\text { may impact efficacy }\end{array}$ & $\begin{array}{l}\text { - Adverse events data not } \\
\text { yet publicly available. } \\
\text { Phase } 3 \text { clinical trials } \\
\text { in progress for full } \\
\text { efficacy \& safety profile }\end{array}$ \\
\hline
\end{tabular}

creased basal metabolic rate, as well as changes in adipose tissue and fluid retention. ${ }^{15-17}$ For T2DM patients, excess weight can increase the risk of mor- tality; up to 8 -fold for those with weight $>40 \%$ above ideal target weight. ${ }^{14}$ In contrast, weight loss can positively impact T2DM, with improvements 
in fasting hyperglycemia reported as early as the first week of weight loss, and accompanying reductions in $\mathrm{HbA}_{1 \mathrm{c}}$ noted with sustained weight loss. ${ }^{14}$ It has been reported that an average weight loss of $\sim 5 \%$ has been associated with an $\sim 0.6 \%$ reduction in $\mathrm{HbA}_{1 \mathrm{c}}{ }^{14}$ Weight loss also improves the cardiovascular risk factors of dyslipidemia and hypertension and decreases the need for glucose-lowering agents. ${ }^{14}$

New T2DM treatments may be needed to address the growing disease burden. This review will discuss 2 new classes of antidiabetic agents, incretin mimetics and dipeptidyl peptidase-IV (DPP-IV) inhibitors. Exenatide (BYETTA ${ }^{\circledR}$; Amylin Pharmaceuticals Inc., San Diego CA and Eli Lilly and Company, Indianapolis, IN) is the first incretin mimetic approved for clinical use by the FDA. In addition, a number of other agents in both drug classes are undergoing late-stage clinical testing (liraglutide, vildagliptin, sitagliptin, saxagliptin). Through different mechanisms, these agents elicit glucoregulatory actions similar to those of the mammalian incretin hormone glucagon-like peptide (GLP)-1.

\section{Incretins}

The role of intestinal peptides in the regulation of postprandial insulin secretion was first identified by the observation that insulin secretion from pancreatic $\beta$-cells was more robust after an oral glucose bolus than after an equivalent, intravenous glucose bolus. ${ }^{18}$ This "incretin effect" was attributed to the insulinotropic action of gut hormones, specifically GLP-1 and glucose-dependent insulinotropic polypeptide (GIP). T2DM patients generally lack the glucose-lowering response to GIP. In contrast, the insulinotropic response to GLP-1 is intact, but circulating levels of postprandial GLP-1 are deficient. Therefore, therapeutic interventions have focused on exerting a pharmacological GLP-1 effect.

The biological activities of GLP- $1^{18-20}$ include (1) glucose-dependent insulin secretion to aid tissue uptake of plasma glucose, (2) suppression of postprandial glucagon to reduce hepatic glucose release, (3) slowing of gastric emptying to avoid overwhelming the circulation with glucose as food is absorbed from the gut, and (4) suppression of food intake (appetite). In addition, animal data suggest that GLP-1 regulates maintenance of pancreatic $\beta$-cell mass as a normal physiologic function.
In mammals, GLP-1 is secreted by mucosal Lcells of the small intestine ${ }^{21}$ and the insulinotropic activity of GLP-1 is mediated through GLP-1 receptors on pancreatic $\beta$-cells. The release of GLP-1 in response to a meal occurs rapidly (within 10 minutes) in healthy individuals and is highly correlated with insulin secretion into the circulatory system. ${ }^{18}$ In T2DM patients, or individuals with impaired glucose tolerance (pre-diabetes), this response is defective, resulting in reduced circulating concentrations of postprandial GLP-1 which contributes to a blunted insulin secretory response to meals. ${ }^{18,19}$

The ability of GLP-1 to control glucose excursions in preclinical diabetes models led to a series of GLP-1 clinical trials in humans. ${ }^{20,22}$ Continuous infusion of GLP-1 into T2DM patients nearly normalized glycemia. The insulinotropic and glucagonostatic actions of GLP-1 were shown to be glucose dependent ${ }^{20}$; in other words, as the action of GLP-1 subsided, euglycemia was restored. The rapid degradation of GLP-1 (half-life less than 2 minutes) by the enzyme DPP-IV limited the feasibility of GLP-1 as a potential therapeutic. ${ }^{22-24}$

\section{Incretin Mimetics}

Incretin mimetics are a new class of pharmacological agents with multiple antihyperglycemic actions that mimic some effects of endogenous incretin hormones, including glucose-dependent enhancement of insulin secretion. Although these agents may exhibit glucoregulatory effects similar to those of GLP-1, their actions might not be mediated solely through the pancreatic GLP-1 receptor. Therefore, the class name "incretin mimetic" is intended to emphasize the glucoregulatory and metabolic effects of these agents, rather than their specific mechanisms of action.

Several incretin mimetic GLP-1 analogues have been developed that are resistant to degradation by DPP-IV. Liraglutide (Novo Nordisk, Copenhagen, Denmark) and CJC-1131 (Conjuchem, Montreal, Canada) have undergone the most extensive testing to date of the GLP-1 analogues. Liraglutide is in phase 2 clinical trials. However, further clinical development of CJC-1131 has been put on hold in favor of CJC-1134, an exendin-4 conjugate, according to 30 September 2005 and 25 January 2006 press releases from Conjuchem and, therefore, will not be discussed further. Exenatide, which is not a 
GLP-1 analogue, is the first incretin mimetic approved for clinical use by the FDA.

\section{Liraglutide}

Liraglutide is a GLP-1 analogue. ${ }^{25}$ In early clinical trials, liraglutide displayed multiple glucoregulatory activities similar to the actions of endogenous GLP-1. ${ }^{26-32}$ Liraglutide suppressed postprandial glucose excursions, reduced fasting plasma glucose concentrations, enhanced first-phase insulin response after meals, and suppressed postprandial plasma glucagon concentrations. In one phase 2 study, liraglutide treatment was associated with reduced $\mathrm{HbA}_{1 \mathrm{c}}(-0.8 \%)$ compared with placebo. Nausea and other gastrointestinal adverse events were the most frequent side effects reported.

\section{Exenatide}

Exendin-4, the naturally occurring form of exenatide, was originally isolated from the salivary secretions of the lizard Heloderma suspectum (Gila monster). ${ }^{33}$ In the Gila monster, exendin-4 circulates after the lizard bites down on its prey (ingestion of a meal) and thus represents the first example of an endocrine hormone secreted from salivary glands. ${ }^{34}$ Exendin-4 is resistant to degradation by mammalian DPP-IV and, thus, has a much longer plasma half-life than GLP-1.

Exenatide and GLP-1 share certain glucoregulatory activities, including glucose-dependent enhancement of insulin secretion, glucose-dependent suppression of inappropriately high glucagon secretion, slowing of gastric emptying, and reduction of food intake. ${ }^{18,35-47}$ In addition, exenatide has been shown to restore first-phase insulin secretion $^{38}$ and to promote $\beta$-cell proliferation and islet neogenesis from precursor cells in both in vitro and in vivo models of diabetes. ${ }^{44,45}$

The results of 3 double-blinded, placebo-controlled exenatide phase 3 clinical trials in T2DM patients treated with metformin, an antidiabetic sulfonylurea, or both, have been reported. ${ }^{35-37}$ Thirty weeks of exenatide dosing $(5 \mu \mathrm{g}$ or $10 \mu \mathrm{g}$ subcutaneously, twice daily) significantly reduced $\mathrm{HbA}_{1 \mathrm{c}}$, fasting plasma glucose, and postprandial glucose excursions. Mean $\mathrm{HbA}_{1 \mathrm{c}}$ reductions from baseline in the $10 \mu \mathrm{g}$ exenatide groups ranged from $-0.9 \%$ to $-0.8 \%$ compared with $+0.1 \%$ to $+0.2 \%$ in the placebo groups. In addition, progressive reductions in body weight were observed, with means ranging from $-2.8 \mathrm{~kg}$ to $-1.6 \mathrm{~kg}$ in the 10 $\mu \mathrm{g}$ dosing groups by week 30, compared with -0.9 $\mathrm{kg}$ to $-0.3 \mathrm{~kg}$ in the placebo group $(P<.05)$. In an interim assessment of ongoing, open-label extensions of these trials, patients with 82 weeks of $10-\mu$ g exenatide exposure had sustained $\mathrm{HbA}_{1 \mathrm{c}}$ reductions from baseline of $-1.1 \pm 0.1 \%$, with $48 \%$ of patients achieving $\mathrm{HbA}_{1 \mathrm{c}} \leq 7 \%$, suggesting durability of glycemic control in this group. ${ }^{47}$ This same patient cohort had progressive weight reductions from baseline of $-4.4 \pm 0.3 \mathrm{~kg}$, supporting the continuing nature of the weight loss in this group. Exenatide was generally well tolerated. Mild-to-moderate nausea was the most common adverse event related to exenatide exposure, and the incidence of nausea decreased with continued treatment. Mild hypoglycemia was most commonly observed in patients also treated with a sulfonylurea.

A subsequent clinical trial was designed to determine whether exenatide could be used as an alternative to insulin glargine. ${ }^{48}$ In this 26-week, randomized, open-label study, the non-inferiority of exenatide to insulin glargine was demonstrated in T2DM patients who were generally middleaged, overweight (mean BMI of $31 \mathrm{~kg} / \mathrm{m}^{2}$ ), and had suboptimal glycemic control with advanced disease duration. At week 26, $\mathrm{HbA}_{1 \mathrm{c}}$ was reduced from baseline by equivalent degrees in both treatment arms (mean $-1.1 \%$ ). In contrast, body weight decreased in exenatide-treated patients (mean -2.3 $\mathrm{kg}$ ), but increased in insulin-treated patients (mean $\pm 1.8 \mathrm{~kg}$ ). The most common adverse event among exenatide-treated patients was mild-tomoderate nausea that decreased in incidence over time. The overall rate of hypoglycemia was not different across treatment arms; however, exenatide patients experienced a lower incidence of nocturnal hypoglycemia coupled with a higher incidence of daytime hypoglycemia compared with insulin glargine.

Pharmacological studies indicate that exenatide dosing is not recommended during the postprandial period, ${ }^{49}$ and exenatide administration is not suitable for patients with severe renal impairment (creatinine clearance $<30 \mathrm{~mL} / \mathrm{min}$ ) or end-stage renal disease. ${ }^{50}$ However, exenatide dosage adjustments are not required when used concomitantly with 3-hydroxy-3-methylglutaryl coenzyme A (HMG-CoA) reductase inhibitors (lovastatin), digoxin, angiotensinconverting enzyme (ACE) inhibitors (lisinopril), or the anticoagulant warfarin. ${ }^{51-54}$ 


\section{DPP-IV Inbibitors}

DPP-IV inhibitors suppress the degradation of a variety of bioactive peptides, including GLP-1, thereby extending their period of action. ${ }^{55}$ Vildagliptin (LAF237; Novartis Pharmaceuticals, Basel, Switzerland) and sitagliptin (MK-0431; Merck Pharmaceuticals, Whitehouse Station, NJ) are furthest along in late-stage clinical development among the DPP-IV inhibitors. Saxagliptin (BMS477118; Bristol-Myers Squibb, Princeton, NJ) is also undergoing clinical testing; however, no clinical results have thus far been published. ${ }^{56}$

\section{Vildagliptin}

In an exploratory 4-week dosing, phase 2 study in early stage T2DM patients, oral vildagliptin was associated with suppression of endogenous DPP-IV activity for $\sim 12$ hours and suppression of postprandial and fasting plasma glucose concentrations. ${ }^{57}$ In addition, basal and postprandial GLP-1 concentrations were increased compared with placebo-treated subjects. Basal and postprandial glucagon levels were reduced, but no change in plasma insulin concentrations was observed. There was no change in body weight during this short-term study. Nasopharyngitis and mild headache were the most common adverse events reported more frequently in the vildagliptin group. No hypoglycemia was observed, as expected for patients with dietcontrolled diabetes.

Three 12-week vildagliptin clinical trials, with the third followed by an open-label extension to 1 year, have been reported. ${ }^{5-60}$ In one 12-week, randomized, placebo-controlled phase 2 study using vildagliptin in T2DM patients taking metformin, vildagliptin-treated subjects had an $\mathrm{HbA}_{1 \mathrm{c}}$ reduction of $-0.7 \pm 0.1 \%$ compared with placebo. ${ }^{59}$ Fasting and postprandial plasma glucose concentrations were reduced, but there was no change in plasma insulin. Vildagliptin was generally well tolerated with cough and nasopharyngitis, the most common adverse events. After 52 weeks of vildagliptin exposure in an extension study patients maintained $\mathrm{HbA}_{1 \mathrm{c}}$ reduction, compared with an $\mathrm{HbA}_{1 \mathrm{c}}$ increase in the placebo plus metformin group, yielding a between treatment arm difference of $-1.1 \pm 0.2 \%$. There was no difference in body weight between treatment arms. Based on fasting glucose and insulin concentrations, there was no change in insulin resistance. However, evaluation of meal test data from a subset of these patients showed a small reduction in postprandial glucose excursions paired with a small increase in postprandial insulin concentrations. ${ }^{60}$

\section{Sitagliptin}

The results of 2 dose ranging, 12-week phase 2 clinical trials in T2DM patients given sitagliptin identified active doses and dosing regimens for further study. ${ }^{61,62}$ In the first study, sitagliptin doses ranging from 25 to $100 \mathrm{mg}$ once daily or $50 \mathrm{mg}$ twice daily were associated with reductions in $\mathrm{HbA}_{1 \mathrm{c}}$ compared with placebo. One hypoglycemic event occurred in each sitagliptin group, and there was no change in body weight. In the second study, reductions in $\mathrm{HbA}_{1 \mathrm{c}}$ were observed with $50 \mathrm{mg}$ of sitagliptin twice daily in concert with no weight change, versus a $1.1 \mathrm{~kg}$ weight gain for T2DM patients treated with glipizide. Hypoglycemia occurred in both groups, but at a higher frequency in the glipizide group. Results of phase 3 trials have not, to date, been published. However, a New Drug Application (NDA) for sitagliptin is under review at the FDA (15 February 2006 Merck \& Co, press release), and more recently, Novartis also filed an NDA for vildagliptin with the FDA (March 30, 2006 Novartis press release).

\section{B-Cell Function}

Halting, or even reversing, the deterioration of the pancreatic $\beta$-cell that accompanies disease progression is the ultimate goal of therapeutic intervention for T2DM. Preclinical data have suggested the possibility that incretin mimetics and DPP-IV inhibitors might have activity in this arena. However, further clinical data are needed to definitively address this issue.

\section{Exenatide As a Treatment Option for Patients with Type 2 Diabetes}

When considering the use of exenatide, several factors should be considered in addition to the topics discussed above:

1. Is your patient taking insulin or other antidiabetic agents, other than metformin or a sulfonylurea? Exenatide is not a substitute for insulin and discontinuing insulin abruptly to initiate exenatide may cause hyperglycemia. In addition, the risk of hypoglycemia for combination therapy with exenatide and insulin is unknown. Concurrent use of exenatide with 
$\alpha$-glucosidase inhibitors, meglitinides, or D-phenylalanine derivatives has not been studied. Clinical trial data for the combination of exenatide with thiazolidinediones are pending.

2. Is your patient taking a sulfonylurea? In 30week clinical trials, ${ }^{42,44}$ the incidence of hypoglycemia was greater for the combination of exenatide and a sulfonylurea than for the combination of placebo and a sulfonylurea.

3. Inform your patients that they may experience nausea at the beginning of treatment. If significant nausea is experienced with the $10 \mu \mathrm{g}$ twice daily dose of exenatide, patients can reduce their dose to $5 \mu \mathrm{g}$ twice daily, and then attempt to return to $10 \mu \mathrm{g}$ at a later time. In addition, anti-emetic agents or over-thecounter remedies may help patients with nausea. Varying administration time may also help, as long as exenatide is taken within 1 hour before eating. If nausea persists, exenatide discontinuation should be considered.

4. What other medications is your patient taking? Exenatide should be used with caution in patients taking oral medications that require rapid gastrointestinal absorption, due to its actions to slow gastric emptying. Patients should be advised to take these medications at least 1 hour before exenatide injection. If oral medications must be ingested with food, patients should take them with a meal or snack when exenatide is not dosed.

\section{Case Report 1}

$\mathrm{RM}$ is a 68 -year-old Caucasian male retired from oil refinery work. His $\mathrm{HbA}_{1 \mathrm{C}}$ was $8.9 \%$ on January 12,2006 with a fasting blood glucose concentration of $153 \mathrm{mg} / \mathrm{dL}$ and postprandial glucose concentrations of 167 to $207 \mathrm{mg} / \mathrm{dL}$. RM's weight was 258 lbs on February 13, 2006 with a body mass index of $38.1 \mathrm{~kg} / \mathrm{m}^{2}$. He was being treated with metformin (1000 mg twice daily), the ACE inhibitor, Toprol XL (50 mg daily), HCTZ (25 mg daily), Norvasc (10 mg daily), and Pravachol (40 mg daily). RM was upgraded from a generic glucose meter to a contour, provided with an 1800 calorie meal plan for weight control, and registered for evening diabetes classes. RM needed to improve his glycemic control, focus on lifestyle interventions, and begin weight loss. After 3 weeks of evening classes focusing on exercise, nutrition, and medication information, RM was started on BYETTA ${ }^{\circledR}$ (5 $\mu \mathrm{g}$ twice daily) on February 21, 2006. RM was contacted by telephone the next day and reported no nausea and a postprandial glucose reading of $130 \mathrm{mg} / \mathrm{dL}$ after his first injection. In addition, he reported not feeling hungry all the time. On April 6, 2006, RM's $\mathrm{HbA}_{1 \mathrm{C}}$ was $7.4 \%$ and his weight was $252 \mathrm{lbs}$. By August 2006, RM's $\mathrm{HbA}_{1 \mathrm{C}}$ was $6.2 \%$ with a fasting blood glucose of 106 to $117 \mathrm{mg} / \mathrm{dL}$, a postprandial glucose range of 78 to $110 \mathrm{mg} / \mathrm{dL}$, and a body weight of 249 lbs. RM reported improved blood pressure and blood sugars, decreased appetite (not "munching" so much), and feeling better overall.

\section{Case Report 2}

John is a 72-year-old, obese male with treated sleep apnea and a 2-year history of type 2 diabetes. He has $\mathrm{HbA}_{1 \mathrm{C}}$ of $7.4 \%$ and routinely checks his morning blood glucose and finds it to be 135 to 170 $\mathrm{mg} / \mathrm{dL}$. John has been on metformin XL (2000 $\mathrm{mg}$ /day) and lisinopril (40 $\mathrm{mg} /$ day), simvastatin (40 mg/day), acetylsalicylic acid (ASA), and atenolol $(50 \mathrm{mg} /$ day). He has a history of syndrome $\mathrm{X}$ and a $50 \%$ right carotid stenosis. He is $5^{\prime} 10^{\prime \prime}$ and weighs 225 lbs. John describes himself as always being hungry for as long as he can remember and has difficulty controlling his diet. Recently, his creatinine has been increasing to $1.3 \mathrm{mg} / \mathrm{dL}$, and a concern was raised about continuing him on metformin. We discussed adding a thiazolidinedione, but because of intermittent edema, a decision was made to put him on exenatide. John was started on $5 \mu \mathrm{g}$ of exenatide subcutaneously, twice daily after being instructed by nursing on injection and dosing procedures. In addition, John's metformin dose was reduced to $1000 \mathrm{mg} /$ day. Over the first week, John experienced some mild nausea but was able to stay on the new medication. He described increased satiety and control over his appetite. This effect started to wane by week 3, and at week 4 his exenatide dosage was increased to $10 \mu \mathrm{g}$ twice daily. Initially, the patient once more reported some transient nausea and earlier satiety. At the time of increased dosage, John was instructed to stop his metformin because his glucose was routinely approximately 90 to $110 \mathrm{mg} / \mathrm{dL}$ during fasting. John lost $3 \mathrm{lbs}$ the first month and $2 \mathrm{lbs}$ the second month, and reported being less hungry; however, over time he had mixed feelings about his decreased enthusiasm for food. He was maintained on the exenatide and by the end of month 3 , his 
$\mathrm{HbA}_{1 \mathrm{c}}$ was at $6.5 \%$ and he has continued a slow but steady weight loss of $1 \mathrm{lb}$ monthly since then.

\section{Concluding Remarks}

Clinical trial data using treatment strategies for type 2 diabetes that take advantage of the glucoregulatory effects of incretin hormones suggest these agents will fill a new niche in diabetes management. The multiple mechanisms of action reported for these agents include enhancement of glucose-dependent insulin secretion, suppression of inappropriately elevated glucagon secretion, slowing of gastric emptying, inhibition of food intake, and possibly, improvement of the underlying disease state through reversal of body weight gain and possible halting of progressive loss of pancreatic function. The problem of weight gain with most currently available diabetes treatments, and the progressive worsening of the T2DM disease state as a consequence, has focused attention on weight modulation as an area of differentiation for future therapeutics. Eighty-two week clinical data for exenatide support progressive reductions in body weight with accompanying sustained improvements in glycemic control. Although incretin mimetics and DPP-IV inhibitors may offer unique benefits to T2DM patients when used as monotherapy or in combination with established therapies for insulin resistance (weight loss, exercise, thiazolidinediones), suppression of glucose production (metformin), and insulin supplementation (insulin, sulfonylureas), much of this has not been researched and reported in the literature.

\section{Note added in proof}

Sitagliptin was approved by the US Food and Drug Administration in October 2006 for the treatment of type 2 diabetes.

\section{References}

1. American Diabetes Association. Postprandial blood glucose. Diabetes Care 2001;24:775-8.

2. American Diabetes Association. Standards of medical care in diabetes. Diabetes Care 2004;27(Suppl 1):S15-35.

3. Kahn SE, Porte D Jr. Pathophysiology of type II diabetes mellitus. In: Porte D Jr and Sherwin RS, editors. Diabetes Mellitus. 5th Ed. Appleton and Lange, Stamford (CT): 1997. pp. 487-512.

4. Weyer C, Bogardus C, Mott DM, Pratley RE. The natural history of insulin secretory dysfunction and insulin resistance in the pathogenesis of type 2 diabetes mellitus. J Clin Invest 1999;104:787-94.

5. UK Prospective Diabetes Study Group: Intensive blood-glucose control with sulphonylureas or insulin compared with conventional treatment and risk of complications in patients with type 2 diabetes (UKPDS 33). Lancet 1998;352:837-53.

6. Harris MI. Racial and ethnic differences in health insurance coverage for adults with diabetes. Diabetes Care 1999;22:1679-82.

7. Koro CE, Bowlin SJ, Bourgeois N, Fedder DO. Glycemic control from 1988 to 2000 among U.S. adults diagnosed with type 2 diabetes: a preliminary report. Diabetes Care 2004;27:17-20.

8. Saydah SH, Fradkin J, Cowie CC. Poor control of risk factors for vascular disease among adults with previously diagnosed diabetes. JAMA 2004;291:33542.

9. DeFronzo RA. Pharmacologic therapy for type 2 diabetes mellitus. Ann Intern Med 1999;131:281303.

10. Kirpichnikov D, McFarlane SI, Sowers JR. Metformin: an update. Ann Intern Med 2002;137:25-33.

11. Nathan DM. Initial management of glycemia in type 2 diabetes mellitus. N Engl J Med 2002;347:1342-9.

12. Riddle MC, Rosenstock J, Gerich J; Insulin Glargine 4002 Study Investigators. The treat-to-target trial: randomized addition of glargine or human $\mathrm{NPH}$ insulin to oral therapy of type 2 diabetic patients. Diabetes Care 2003;26:3080-6.

13. Dailey GE, Noor MA, Park JS, Bruce S, Fiedorek FT. Glycemic control with glyburide/metformin tablets in combination with rosiglitazone in patients with type 2 diabetes: a randomized, double-blind trial. Am J Med 2004;116:223-9.

14. Maggio CA, Pi-Sunyer FX. Obesity and type 2 diabetes. Endocrinol Metab Clin North Am 2003;32: 805-22.

15. Yki-Jarvinen, H. Combination therapies with insulin in type 2 diabetes. Diabetes Care 2001;24:758-67.

16. Purnell JQ, Weyer C. Weight effect of current and experimental drugs for diabetes mellitus: from promotion to alleviation of obesity. Treat Endocrinol 2003;2:33-47.

17. Makimattila S, Nikkila K, Yki-Jarvinen H. Causes of weight gain during insulin therapy with and without metformin in patients with type II diabetes mellitus. Diabetologia 1999;42:406-12.

18. Holst JJ, Gromada J. Role of incretin hormones in the regulation of insulin secretion in diabetic and nondiabetic humans. Am J Physiol Endocrinol Metab 2004;287:E199-206.

19. Deacon CF. Therapeutic strategies based on glucagon-like peptide 1. Diabetes 2004;53:2181-9.

20. Holst JJ. Therapy of type 2 diabetes mellitus based on the action of glucagon-like peptide-1. Diabetes/ Metab Res Rev 2002;18:430-41. 
21. Drucker DJ. Glucagon-like peptides. Diabetes 1998; 47:159-69.

22. Zander M, Madsbad S, Madsen JL, Holst JJ. Effect of 6-week course of glucagon-like peptide 1 on glycaemic control, insulin sensitivity, and $\beta$-cell function in type 2 diabetes: a parallel-group study. Lancet 2002;359:824-30.

23. Kieffer TJ, McIntosh CH, Pederson RA. Degradation of glucose-dependent insulinotropic polypeptide and truncated glucagon-like peptide 1 in vitro and in vivo by dipeptidyl peptidase IV. Endocrinology 1995;136:3585-96.

24. Deacon CF, Nauck MA, Toft-Nielsen M, Pridal L, Willms B, Holst JJ. Both subcutaneously and intravenously administered glucagon-like peptide I are rapidly degraded from the $\mathrm{NH}_{2}$ terminus in type II diabetic patients and in healthy subjects. Diabetes 1995;44:1126-31.

25. Rolin B, Larsen MO, Gotfredsen CF, et al. The long-acting GLP-1 derivative NN2211 ameliorates glycemia and increases $\beta$-cell mass in diabetic mice. Am J Physiol Endocrionol Metab 2002;283:E74552.

26. Degn KB, Juhl CB, Sturis J, et al. One week's treatment with the long-acting glucagon-like peptide 1 derivative liraglutide (NN2211) markedly improves 24-h glycemia and $\alpha$ - and $\beta$-cell function and reduces endogenous glucose release in patients with type 2 diabetes. Diabetes 2004;53:1187-94.

27. Chang AM, Jakobsen G, Sturis J, et al. The GLP-1 derivative NN2211 restores $\beta$-cell sensitivity to glucose in type 2 diabetic patients after a single dose. Diabetes 2003;52:1786-91.

28. Juhl CB, Hollingdal M, Sturis J, et al. Bedtime administration of NN2211, a long-acting GLP-1 derivative, substantially reduces fasting and postprandial glycemia in type 2 diabetes. Diabetes 2002;51: 424-9.

29. Harder H, Nielsen L, Thi TT, Astrup A. The effect of liraglutide, a long-acting glucagon-like peptide 1 derivative, on glycemic control, body composition, and 24-h energy expenditure in patients with type 2 diabetes. Diabetes Care 2004;27:1915-21.

30. Madsbad S, Schmitz O, Ranstam J, Jakobsen G, Matthews DR. Improved glycemic control with no weight increase in patients with type 2 diabetes after once-daily treatment with the long-acting glucagonlike peptide 1 analog liraglutide (NN2211): a 12week, double-blind, randomized, controlled trial. Diabetes Care 2004;27:1335-42.

31. Elbrønd B, Jakobsen G, Larsen S, et al. Pharmacokinetics, pharmacodynamics, safety, and tolerability of a single-dose of NN2211, a long-acting glucagonlike peptide 1 derivative, in healthy male subjects. Diabetes Care 2002;25:1398-404.

32. Feinglos MN, Saad MF, Pi-Sunyert FX, An B, Santiago $\mathrm{O}$; on behalf of the liraglutide dose-response study group. Effects of liraglutide (NN2211), a long- acting GLP-1 analogue, on glycaemic control and bodyweight in subjects with type 2 diabetes. Diabetic Med 2005;22:1016-23.

33. Eng J, Kleinman WA, Singh L, Singh G, Raufman JP. Isolation and characterization of exendin-4, an exendin-3 analogue, from Heloderma suspectum venom. J Biol Chem 1992;267:7402-5.

34. Young AA. Glucagon-like peptide-1, exendin and insulin sensitivity. In: Hansen B, Shafrir E, editors. Insulin resistance and insulin resistance syndrome. New York: Harwood Academic Press, 2002;235-62.

35. Buse JB, Henry RR, Han J, Kim DD, Fineman MS, Baron AD. Effects of exenatide (exendin-4) on glycemic control over 30 weeks in sulfonylurea-treated patients with type 2 diabetes. Diabetes Care 2004; 27:2628-35.

36. DeFronzo RA, Ratner RE, Han J, Kim DD, Fineman MS, Baron AD. Effects of exenatide (exendin-4) on glycemic control and weight over 30 weeks in metformin-treated patients with type 2 diabetes. Diabetes Care 2005;28:1092-100.

37. Kendall DM, Riddle MC, Rosenstock J, et al. Effects of exenatide (exendin-4) on glycemic control over 30 weeks in patients with type 2 diabetes treated with metformin and a sulfonylurea. Diabetes Care 2005; 28:1083-91.

38. Fehse F, Trautmann M, Holst JJ, et al. Exenatide augments first- and second-phase insulin secretion in response to intravenous glucose in subjects with type 2 diabetes. J Clin Endocr Metab 2005;90:5991-7.

39. Degn KB, Brock B, Juhl CB, et al. Effect of intravenous infusion of exenatide (synthetic exendin-4) on glucose-dependent insulin secretion and counterregulation during hypoglycemia. Diabetes 2004;53: 2397-403.

40. Kolterman OG, Buse JB, Fineman MS, et al. Synthetic exendin-4 (exenatide) significantly reduces postprandial and fasting plasma glucose in subjects with type 2 diabetes. J Clin Endocrinol Metab 2003; 88:3082-9.

41. Kolterman OG, Kim DD, Shen L, et al. Pharmacokinetics, pharmacodynamics, and safety of exenatide in patients with type 2 diabetes mellitus. Am J Health-Sys Pharmacy 2005;62:173-81.

42. Fineman MS, Bicsak TA, Shen LZ, et al. Effect on glycemic control of exenatide (synthetic exendin-4) additive to existing metformin and/or sulfonylurea treatment in patients with type 2 diabetes. Diabetes Care 2003;26:2370-7.

43. Fineman MS, Shen LZ, Taylor K, Kim DD, Baron AD. Effectiveness of progressive dose-escalation of exenatide (exendin-4) in reducing dose-limiting sideeffects in subjects with type 2 diabetes. Diabetes/ Metab Res Rev 2004;20:411-7.

44. Nielsen LL, Young AA, Parkes DG. Pharmacology of exenatide (synthetic exendin-4): a potential therapeutic for improved glycemic control of type 2 diabetes. Regul Pept 2004;117:77-88. 
45. Gedulin BR, Nikoulina SE, Smith PA, et al. Exenatide (exendin-4) improves insulin sensitivity and $\beta$-cell mass in insulin-resistant obese $f a / f a$ Zucker rats independent of glycemia and body weight. Endocrinology 2005;146:2069-76.

46. Edwards CM, Stanley SA, Davis R, et al. Exendin-4 reduces fasting and postprandial glucose and decreases energy intake in healthy volunteers. Am J Physiol Endocrinol Metab 2001;281:E155-61.

47. Blonde L, Klein EJ, Han J, et al. Interim analysis of the effects of exenatide treatment on A1C, weight and cardiovascular risk factors over 82 weeks in overweight patients with type 2 diabetes. Diabetes Obes Metab 2006;8:436-47.

48. Heine RJ, Van Gaal LF, Johns D, Mihm MJ, Widel MH, Brodows RG; for the GWAA study group. Exenatide versus insulin glargine in patients with suboptimally controlled type 2 diabetes. Ann Intern Med 2005;143:559-69.

49. Linnebjerg H, Kothare PA, Skrivanek Z, et al. Exenatide: effect of injection time on postprandial glucose in patients with type 2 diabetes. Diabet Med 2006;23:240-5.

50. Linnebjerg H, Kothare PA, Park S, et al. Effect of renal impairment on the pharmacokinetics of exenatide. Br J Clin Pharm 2006 In press.

51. BYETTA ${ }^{\circledR}$ prescribing information. Available from: http://www.byetta.com/index.jsp? reqNavId $=0$. BYETTA $^{\circledR}$ is a registered trademark of Amylin Pharmaceuticals, Inc, San Diego, CA.

52. Kothare PA, Soon DK, Linnebjerg H, et al. Effect of exenatide on the steady-state pharmacokinetics of digoxin. J Clin Pharmacol 2005;45:1032-7.

53. Linnebjerg H, Kothare P, Park S, Atkins M, Mace K, Mitchell M. Effects of exenatide on lisinopril pharmacokinetics and pharmacodynamics in patients treated for hypertension. Basic Clin Pharm Tox 2005;97(Suppl 1):87.

54. Soon D, Kothare P, Linnebjerg H, Park S, Yuen E, Mace K. Effect of exenatide on the pharmacokinetics and pharmacodynamics of warfarin in healthy males. Clin Pharm Ther 2006 In press.

55. Weber AE. Dipeptidyl peptidase IV inhibitors for the treatment of diabetes. J Med Chem 2004;47: 4135-41.

56. Augeri DJ, Robl JA, Betebenner DA, et al. Discovery and preclinical profile of saxagliptin (BMS-477118): a highly potent, long-acting, orally active dipeptidyl peptidase IV inhibitor for the treatment of type 2 diabetes. J Med Chem 2005;48:5025-37.

57. Ahrén B, Landin-Olsson M, Jansson P, Svensson M, Holmes D, Schweizer A. Inhibition of dipeptidyl peptidase-4 reduces glycemia, sustains insulin levels, and reduces glucagon levels in type 2 diabetes. J Clin Endocrinol Metab 2004;89:2078-84.

58. Ristic S., Byiers S, Foley J, Holmes D. Improved glycaemic control with dipeptidyl peptidase-4 inhibition in patients with type 2 diabetes: vildagliptin (LAF237) dose response. Diabetes Obes Metab 2005;7:692-8.

59. Ahrén B, Gomis R, Standl E, Mills D, Schweizer A. Twelve- and 52-week efficacy of the dipeptidyl peptidase IV inhibitor LAF237 in metformin-treated patients with type 2 diabetes. Diabetes Care 2004; 27:2874-80.

60. Ahrén B, Giovanni P, Foley JE, Schweizer A. Improved meal-related $\beta$-cell function and insulin sensitivity by the dipeptidyl peptidase-IV inhibitor vildagliptin in metformin-treated patients with type 2 diabetes over 1 year. Diabetes Care 2005;28:193640.

61. Hanefeld M, Herman G, Mickel C, et al. Effect of MK-0431, a dipeptidyl peptidase IV (DPP-IV) inhibitor, on glycemic control after 12 weeks in patients with type 2 diabetes. Diabetologia 2005; 48(Suppl 1):A287.

62. Scott R, Herman G, Zhao P, et al. Twelve-week efficacy and tolerability of MK-0431, a dipeptidyl peptidase IV (DPP-IV) inhibitor, in the treatment of type 2 diabetes. Diabetologia 2005;48(Suppl 1): A287. 